\title{
A területfejlesztés irányelvei Németországban - aktuális fejlemények
}

\section{General principles of spatial development in Germany - newest developments}

\author{
BRENNER JÁNOS
}

\begin{abstract}
BRENNER János: címzetes egyetemi tanár, Budapesti Műszaki Egyetem; építésügyi igazgató, Szövetségi Közlekedési és Digitális Infrastruktúra Minisztérium, Berlin; brennerjanos@googlemail.com
\end{abstract}

János BRENNER: honorary professor, Budapest University of Technology and Economics; Baudirektor, Federal Ministry of Transport and Digital Infrastructure, Berlin; brennerjanos@googlemail.com

\section{Bevezetésképpen: egy kis jogi kitérő}

Mindjárt a cikk elején a szerzőnek akaratán kívül fogalmi zavart kell okoznia a magyar olvasók számára. Németországban a területfejlesztés és a területrendezés fogalmát sem a szakmában, sem a politikában nem különítik el világosan. Durván leegyszerüsítve természetesen itt is érvényes (akárcsak a települések szintjén), hogy a fejlesztés a „Mit és mennyit?”, a rendezés pedig a „Hol és hogyan?” kérdésekre válaszol. Magyar szempontból nehezíti a helyzet megértését Németország föderatív államszerkezete: noha szövetségi szinten létezik területrendezési törvény (Raumordnungsgesetz - ROG) (BMJV 2008), de országos (szövetségi szintű, jogszabályban rögzített) területrendezési terv nincsen. A területrendezési törvény formálisan a területrendezést szabályozza, de részben a területfejlesztésről szól, pl. mindjárt a 2. § 1. bekezdésben: „A területrendezés alapelveit a fenntartható területfejlesztés (...) irányelve értelmében kell alkalmazni és szükség szerint területrendezési tervekben kell konkretizálni." A területrendezési törvény 2 . § 2. bekezdése is lényegében a fejlesztésről szól: „A Németországi Szövetségi Köztársaság összterületén és résztérségeiben kiegyenlitett társadalmi, infrastrukturális, gazdasági, ökológiai és kulturális viszonyokra kell törekedni. A közszolgáltatásokat fenntartható módon kell biztositani, a fenntartható gazdasági növekedést és innovációt támogatni kell, a fejlesztés lehetőségeit biztositani és a forrásokat tartósan óvni kell. Ezen

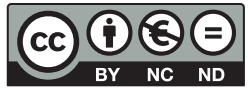


feladatokat mind az agglomerációkban, mind a vidéki térségekben, szerkezetileg gyenge és erős térségekben el kell látni." Bonyolítja a képet, hogy a szövetségi területrendezési törvény az alaptörvény (Grundgesetz - GG) szerint azon törvények kategóriájába tartozik, amelytől a tartományok bizonyos feltételek mellett eltérhetnek (GG 72. cikkely 3. bekezdés 4. pont). Ezzel a felhatalmazással eddig néhány kivételtől eltekintve csak Bajorország élt - a szövetségi törvényhozás természetesen olyan szabályozásokra törekszik, amelyek a tartományokkal összhangban jönnek létre, végszükség esetén pedig a szövetségi törvényhozás „visszahozhatja” saját szabályozását egy új törvénnyel. Ugyanakkor a tartományoknak magyar fogalmak szerint van saját területfejlesztési és területrendezési törvénye (Landesplanungsgesetz), amely mind a tartományi területfejlesztési, mind a területrendezési terveket szabályozza. A szövetségi területrendezési törvény lényegében csak a tartományi és a regionális (a tartományi szint alatti) tervezés szükségességét mondja ki, azok lényegi tartalmára tér ki (pl. térségi kategóriák, településhálózati koncepció, beépített és szabad területek szerkezete, vonalas infrastruktúra), valamint a tervekben megadott „célok, alapelvek és egyéb követelmények" (ROG 3. § 1. bekezdés) a felsorolás szerint csökkenő sorrendű jogi érvényét határozza meg. A „céloktól” a településrendezési tervekben eltérni nem szabad, az „alapelvek” és az „egyéb követelmények” mérlegelés tárgyát képezik. Ez magyar füleknek valószínűleg szintén szokatlanul hangzik, hiszen köznapi nyelvhasználat szerint az alapelveket szoktuk sérthetetlennek tekinteni, a célokat kevésbé, itt pont fordítva van - a magyarázat az, hogy a célok az alapelvek térbeli konkretizálásának számítanak, bár a szóhasználat németül sem következetes, mert az alapelvek is többé-kevésbé térbeli megfogalmazást nyernek.

\section{A 2006. évi irányelvek és a 2013-ban kezdett módosítási vita}

E háttér ismeretében nem csoda, hogy a szövetségi kormány és a tartományi kormányok évtizedek óta szükségesnek látják, hogy egy nem jogszabályi szintű országos rendezési tervben, de legalább egy „policy paper” jellegű dokumentumban megegyezésre jussanak és közösen irányt szabjanak az ország területi fejlődésének. (Készséggel állok rendelkezésre további szemantikai-terminológiai problémák esetén, mert a német Entwicklung szó nem tesz különbséget a fejlödés és a fejlesztés között, ezt csak a szövegkörnyezetből lehet levezetni.) Több, ezt megelőző dokumentum után 2006. június 30-án a területrendezésért felelős szövetségi és tartományi miniszterek konferenciája (Ministerkonferenz für Raumordnung - MKRO) jóváhagyta A területfejlesztés irányelvei és cselekvési stratégiái Németországban címü dokumentumot (BMVBS 2006).

2013. augusztus 26-án az MKRO módosítási konzultációt kezdeményezett és új tervezetet tett közzé (MKRO 2013). A tervezet szerint az alábbi tényezők indokolják a módosítást, illetve a részbeni újrafogalmazást: 
1. a demográfiai átalakulás, különös tekintettel a stagnáló, illetve fogyó népességű régiókra,

2. az adaptáció a klímaváltozáshoz,

3. az „energiafordulat“ térbeli következményei,

4. az erőteljesebb participáció iránti igény,

5. a csökkenő anyagi lehetőségek,

6. az EU területi kohéziós céljai,

7. a tengeri területrendezés mint új „müfaj”,

8. a területfelhasználási igények és a védelmet igénylő területi érdekek között erősödő konfliktus,

9. a globalizáció okozta növekvő közlekedési és logisztikai feladatok.

Messze túllépne a cikk határain a tényezők részletezése, mindössze az első háromra mint évszázados léptékü feladatra szeretnék kitérni.

Noha Németország éppen az utóbbi években közismerten (a magyarok számára is) attraktív bevándorlási célországgá vált, hosszú távon még viszonylag nagymértékű migrációs nyereség sem tudja a népességfogyást kiegyenlíteni, a társadalom tehát „gyérebb, idősebb és színesebb” lesz, ahogy azt szállóige-szerüen szokták emlegetni. A hosszú távú trendeket az 1. táblázat mutatja.

Ha mindennek térbeli vetületét összevetjük a klímaváltozás várható intenzitásával, akkor a következő sajnálatos felismerésre kell jutnunk: a klímaváltozásnak esze ágában sincs megtenni nekünk azt a szívességet, hogy ott történjen, ahol a népesség fogyóban van, azaz egyre kevesebb embert érintsen. Éppen ellenkezőleg: a dinamikusan fejlődő Felső-Bajororoszágot és a Rajna völgyét érinti erősen, míg a keletnémet tartományok viszonylag kevésbé érintettek (1. ábra).

A harmadik lényeges tényező a szövetségi kormány által a fukusimai reaktorkatasztrófa hatására a radikális energiapolitikai váltásról hozott döntés. Németország 2022-ig valamennyi atomerőművét üzemen kívül akarja helyezni. Már közvetlenül a katasztrófa után hét atomerőművet lekapcsoltak a hálózatról

1. táblázat: Németország népessége életkori összetétel alapján 1950 és 2050 között (2010-től becslések)

Population of Germany according to age groups, between 1950 and 2050 (projections after 2010)

\begin{tabular}{cccccc}
\hline \multirow{2}{*}{ Év } & Népességszámaz & \multicolumn{4}{c}{ Ebböl } \\
\cline { 3 - 5 } & év végén (millió fó) & $\begin{array}{c}\text { 20 évesnél } \\
\text { fiatalabb (\%) }\end{array}$ & $\begin{array}{c}20-59 \text { év közötti } \\
(\%)\end{array}$ & $\begin{array}{c}\text { 60 éves és } \\
\text { idösebb (\%) }\end{array}$ & $\begin{array}{c}\text { 80 éves és } \\
\text { idösebb (\%) }\end{array}$ \\
\hline 1950 & 69,3 & 30,4 & 55,0 & 14,6 & 1,0 \\
1970 & 78,1 & 30,0 & 50,1 & 19,9 & 2,0 \\
1990 & 79,8 & 21,7 & 57,9 & 20,4 & 3,8 \\
2001 & 82,4 & 20,9 & 55,0 & 24,1 & 3,9 \\
2010 & 83,1 & 18,7 & 55,7 & 25,6 & 5,0 \\
2030 & 81,2 & 17,1 & 48,5 & 34,4 & 7,3 \\
2050 & 75,1 & 16,1 & 47,2 & 36,7 & 12,1 \\
\hline
\end{tabular}

Forrás: Statistisches Bundesamt 10. koordinált népességprognózisa. 
1. ábra: A népesség térbeli megoszlásának alakulása (balra)

és a klímaváltozás várható intenzitása (jobbra)

Spatial distribution of the population (left) and the expected intensity of climate change (right)

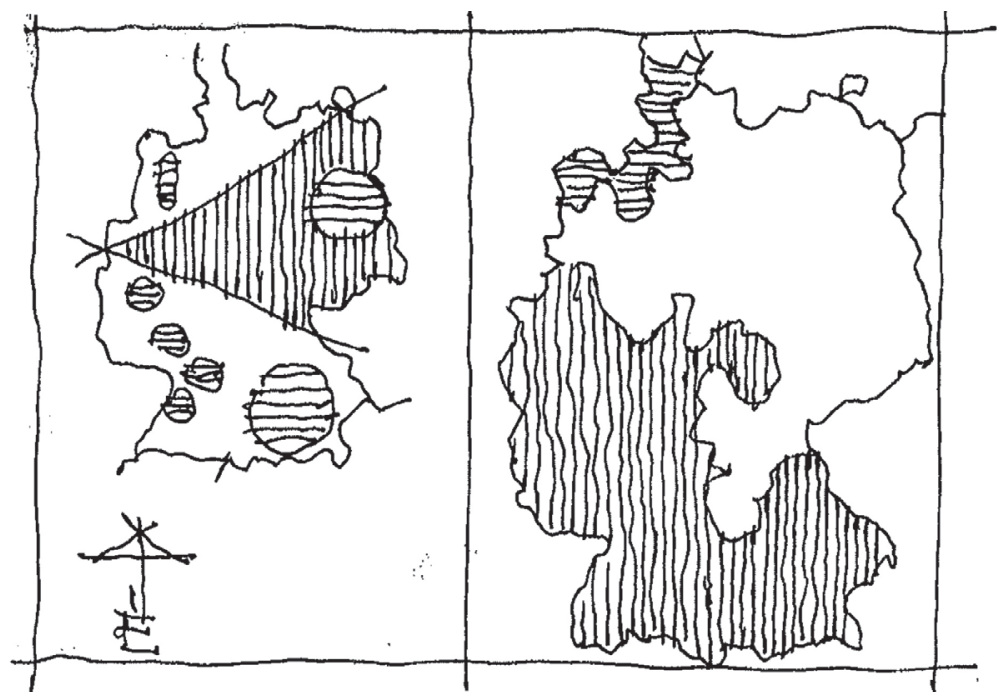

Bal oldali ábra: függóleges sraffozás: a "fogyási ék" a keleti tartományokból a Ruhr-vidék felé; vizszintes sraffozás: gyarapodás. Jobb oldali ábra: függóleges sraffozás: a felmelegedés hatásai; vízszintes sraffozás: a tengeri viharok és a tengerszint-emelkedés hatásai.

A szerző vázlata a BBSR adatai alapján.

(egy közülük amúgy is üzemen kívül volt), a többi kilenc 2015-től lépésről lépésre következik. A kormány emellett továbbra is ragaszkodik 2010-ben hozott döntéseihez, melyek az atomerőművek működésének meghosszabbítását és az ezért kivetett, az alternatív energiahordozók támogatására szánt nukleárisfütőanyag-adó kivetését tételezték fel. A program szerint az üvegházgázok kibocsátását 1990-hez képest 2020-ig 40\%-kal, 2050-ig legalább 80\%-kal kell csökkenteni. Ugyanakkor a határozatok szerint 2020-ra a megújuló forrásokból származó energiának (nap- és szélenergia, biomassza stb.) az áramfogyasztás legalább 35\%-át kell fedeznie a mai 17\%-kal szemben. A kormány a megújuló energiákhoz vezető „hídként” modern és magas hatásfokú szén- és gázerőmüvek mellett tette le a voksát. Ez nem egészen problémamentes, mert egyrészt nem vág egybe a fosszilis energiahordozók kímélésének és a szén-dioxid-kibocsátás csökkentésének céljával, másrészt mert igen valószínű, hogy minden új erőmű a helyi lakosság ellenállásába ütközik.

A döntés mindenesetre megszületett, térbeli és társadalmi problémákkal. Az ország egészét nézve a megújuló energiák fő forrásai elsősorban ÉszakNémetországban találhatók. A tengeren, a partokon és a Germán-alföldön viszonylag rendszeresen fúj a szél, szintén a Germán-alföldön állítható elő nagy mennyiségü biomassza. A fó fogyasztók, nagy agglomerációk (Berlin és Hamburg kivételével) a Ruhr-vidéktől a Rajna-tengelyen át Frankfurt, Stuttgart, München 
dinamikusan fejlődő térségeiig mind Németország középső és déli területein találhatók - akárcsak az atomerőművek többsége. Minthogy az elektromos energiát el kell juttatni a termelőktől a fogyasztókig, logikusan következik, hogy az országot az eddiginél jóval több észak-dél irányú magasfeszültségü távvezetékkel kell behálózni, ami szintén nem okvetlenül vág egybe a helyi lakosság elképzeléseivel.

E tényezők ismeretében fogalmazta meg az MKRO a területfejlesztés irányelveinek módosítási javaslatát.

\section{Első irányelv: a versenyképesség erősitése}

Valamennyi térséget helyzetbe kell hozni ahhoz, hogy a régió különleges adottságainak erősitésével elsősorban a tudásalapú társadalom fejlesztéséhez járuljon hozzá. Németországban 11 európai jelentőségü metropolisztérséget tartanak számon: Berlin-Brandenburg, Hamburg, München, Frankfurt és Rajna-Majna-térség, Rajna-Ruhr-térség, Stuttgart, Halle-Lipcse-,,szász háromszög”, Hannover-Braunschweig-Göttingen, Nürnberg, Rajna-Neckar-térség, Bréma-Oldenburg. E teljesítőképes, „húzó” térségeket a dokumentum továbbra is a fejlesztéspolitika egyik központi elemének tartja.

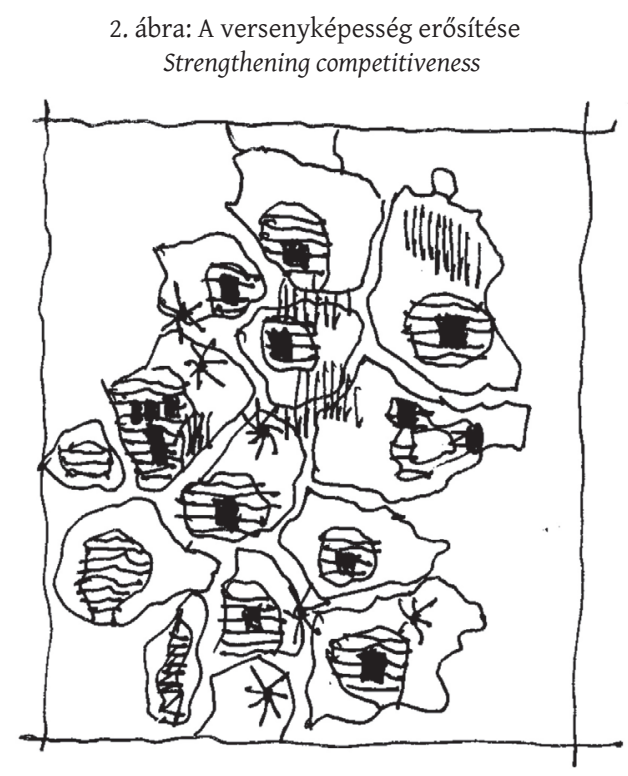

A négyzetek a metropoliszrégiók magját, a vízszintesen sraffozott felületek a metropolisztérségek szúkebb agglomerációs területeit, a csillagok az ezeken kívüli növekedési gócokat, a függölegesen sraffozott felületek a „különleges szerkezeti cselekvést igénylo” térségeket jelölik (határokon átnyúló funkcionális ábrázolás).

MKRO 2013 alapján a szerzö vázlata. (A forrás munkaközi anyag, fekete-fehéren jól reprodukálható ábrázolás sajnos nem állt rendelkezésre, ezért a szerző néhány színes ábrát erősen egyszerüsítve átrajzolt.) 
Ezen kívül dinamikus fejlődés tapasztalható néhány, a metropolisztérségeken kívül eső területen: Emsland, a Boden-tó környéke, Délkelet-Bajorország. A „különleges szerkezeti cselekvést igénylő térségek” ügyében (a 2006. évi változatban még „stabilizálandó térségek" néven szerepelt, pl. Elő-Pomeránia és Nyugat-Pfalz: részben kedvezőtlen fekvésű, részben korán iparosított térségek, átlag alatti fejlődéssel és demográfiai válságtünetekkel) a cselekvési javaslatok kissé szúkszavúak, a régiók endogén forrásainak jobb mozgósítását javasolják, továbbá a vidékfejlesztési programokkal együtt integrált fejlesztési stratégiák kialakítását (2. ábra).

\section{Második irányelv: a közszolgáltatások biztositása}

A területfejlesztési politika alkotmányos alapelve, hogy Németország valamennyi térségében az életfeltételek legyenek azonos értéküek (GG 72. cikkely 2. bekezdés). Az irányelvet azonban a demográfiai átalakulás és a szükülő pénzügyi források miatt egyre nehezebb valóra váltani. A dilemma a társadalmilag igazságos és az anyagilag hatékony fejlesztés között elméletileg is csaknem feloldhatatlan, a gyakorlatban köztes megoldásokkal kísérleteznek, mint pl. Brandenburg tartomány a „horgonyvárosokkal”, amelyek biztosítják a gyéren lakott vidéki térségekben az alapfunkciókat, félig nyitva hagyva a nem világosan meghatározott szerepkörü települések fejlesztésének kérdését. A településhálózati koncepciót mint az infrastruktúra és a közszolgáltatások eddigi vázát a demográfiai átalakuláshoz kell

3. ábra: A közszolgáltatások biztosítása Providing public services

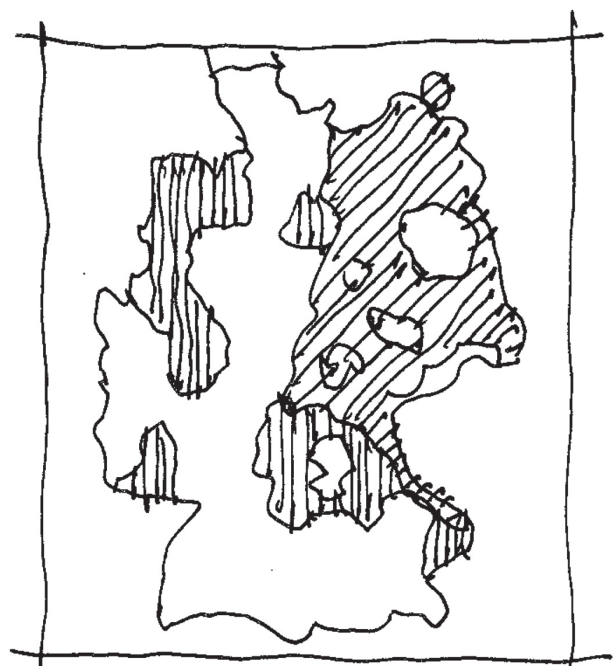

A ferde sraffozás a demográfiai változás által okozott erơs, a függóleges sraffozás a közepes, a jelölés nélküli terület a gyenge cselekvési szükséget jelöli.

MKRO 2013 alapján a szerző vázlata. 
igazítani, a koncepciót „szorosabbra kell húzni” (vö. 3. ábra). Különösen az egészségügyi, a művelődési és oktatási, valamint a közlekedési ágazatban az intézmények müködőképességét minimális követelmények alapján garantálni kell. Ezért vita és egyeztetés szükséges az érintettekkel arról, hogy a jövőben mi lesz a közszolgáltatások „kemény”, tovább nem redukálható köre, hol és hogyan lesz a kínálat a térben megszervezve. Az ellátás minőségét modern, térben és idóben rugalmas szervezési és kínálati formákkal is ki kell egészíteni: „service to people”, hívható kisbuszos szolgáltatások stb.

Mindennek eszközeiként a tervezet többek közt a településhálózati koncepció következetes alkalmazását, az önkormányzatok együttműködésének támogatását és a Bundesministerium für Verkehr und digitale Infrastruktur (BMVI, Szövetségi Közlekedési és Digitális Infrastruktúra Minisztérium) által támogatott területfejlesztési modellprojekteket (Modellvorhaben der Raumordnung - MORO) ajánlja.

\section{Harmadik irányelv: a területfelhasználás irányitása}

A területrendezésnek és -fejlesztésnek - a növekvő területfelhasználási konfliktusok és a takarékos területfelhasználás céljának ismeretében - a források és a fejlesztési lehetőségek aktív menedzselésével biztosítania kell az optimális területfelhasználást mint a fenntartható fejlődés egyik fontos elemét.

4. ábra: A területfelhasználás irányítása Managing land use

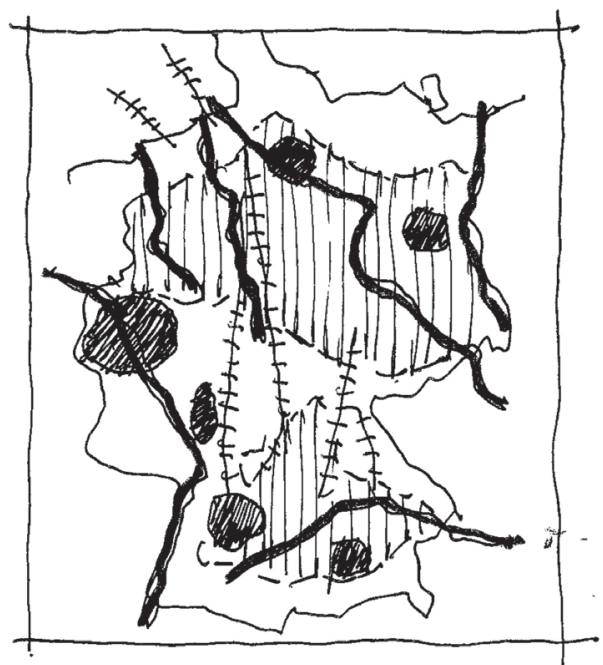

A vastag fekete vonalak a folyamok menti árvízvédelmi és természetvédelmi célokat, a fekete foltok néhány különösen sürü, urbanizált területet, a függöleges sraffozás nagy mezögazdasági és biomassza-potenciállal rendelkező területeket, az áthúzott vonalak néhány (nem valamennyi) magasfeszültségü távvezeték-korridort jelölnek. MKRO 2013 alapján a szerző vázlata. 
Előtérben áll a szabad területek védelme és a szabad területek beépítésének csökkentése, a szervesen kialakult kultúrtájak védelme és fejlesztése, a biodiverzitás megőrzése - a kultúrtáj egyúttal az urbanizált térségeket is stabilizálja. A 2013. évi térképi ábrázolás „energiafordulatnak” köszönhető új elemei a magasfeszültségü távvezetékek korridorjai és az offshore szélenergiaparkok hálózati csatlakozásai (4. ábra).

\section{Kitekintés}

Az irányelvek módosításának bőséges vitaanyaga van, amelyek részleteire kitérni itt túl hosszadalmas lenne, ezek a BMVI honlapján hozzáférhetők (BMVI 2015a). Itt csak a legfontosabb aktuális fejleményre szeretnék kitérni: Rainer Bomba BMVI államtitkár elnöklete alatt az MKRO 2015. január 22-i ülésén a BMVI sajtóközleménye szerint (BMVI 2015b) határozatot hozott, miszerint „a klímavédelmet és az energiafordulatot önálló irányelvben fogja kiemelni azért, hogy a területrendezés mint ágazatokat átívelö politika szövetségi és tartományi szinten még világosabb alakitó és kiegyenlito” hatással müködhessen. A területi tervezés társadalom-, gazdaság- és környezetpolitikai jelentöségét a klímaváltozáshoz való szükséges adaptációnál ily módon még tisztábban kell hangsúlyozni." Bomba államtitkár szó szerint így nyilatkozott: „Szükségünk van a területrendezésre a klímaadaptációnál és az energiafordulat megvalósításánál. Konkrétan például a sok szélenergiaparkról vagy az árvízcsúcsok csökkentését szolgáló tározókról van szó. Ezekben rá vagyunk utalva a területrendezés tervezési és koordinációs teljesítményére. Szükségünk van a különféle érdekek igazságos kiegyenlítésére, hogy ne gázoljunk bele egymás területfelhasználási igényeibe. A területfejlesztés klímaadaptációs és energiafordulati cselekvési stratégiájával az érdekek kiegyenlítésének célját még intenzívebben fogjuk követni. Pozitív jel, hogy a tartományi területrendezési miniszterek támogatásukat fejezték ki. Gyorsan kell cselekednünk, a klímaváltozás nem vár ránk." (BMVI 2015a)

A határozat alapján az MKRO dolgozik az önálló irányelv megfogalmazásán és térképi ábrázolásán, várhatóan hamarosan elfogadják az irányelveket. Az irányelveket ezután élettel kell megtölteni a tartományok, régiók, önkormányzatok és - nem utolsósorban - a civil társadalom szereplőinek összefogásával. 


\section{Irodalom}

BMJV (2008): Raumordnungsgesetz vom 22. Dezember 2008. http://www.gesetze-im-internet.de/rog_2008/ (Letöltés: 2015. március 3.)

BMVI (2015a): Leitbilder Raumentwicklung. http://www.bmvi.de/DE/DasMinisterium/Raumentwicklung/ Leitbilder/leitbilder_node.html (Letöltés: 2015. március 3.)

BMVI (2015b): Pressemitteilung des BMVI Nr. 006/2015 vom 23.01.2015. http://www.bmvi.de/SharedDocs/DE/ Pressemitteilungen/2015/006-bomba-ministerkonferenz-f\%C3\%BCrraumordnung.html?link ToOverview=DE\%2FPresse\%2FPressemitteilungen\%2Fpressemitteilungen_node.html\%23id152046 (Letöltés: 2015. március 3.)

Bundesministerium für Verkehr, Bau und Stadtentwicklung (BMVBS) (2006): Leitbilder und Handlungsstrategien für die Raumentwicklung in Deutschland, verabschiedet von der Ministerkonferenz für Raumordnung am 30.06.2006. Berlin. http://www.bbsr.bund.de/BBSR/DE/Veroeffentlichungen/ BMVBS/Sonderveroeffentlichungen/2006/leitbilder.html?nn=412686 (Letöltés: 2015. március 3.)

Ministerkonferenz für Raumordnung (MKRO) (2013): Entwurf Leitbilder und Handlungsstrategien für die Raumentwicklung in Deutschland 2013. MKRO-Beschluss vom 03.06.2013.http://www.bmvi.de/ SharedDocs/DE/Anlage/Raumentwicklung/leitbilder-und-handlungsstrategien-entwurf-03-06-2013. html (Letöltés: 2015. március 3.) 